\title{
IMPLEMENTASI KEBIJAKAN RETRIBUSI PELAYANAN PEMAKAMAN DAN PENGABUAN MAYAT DI KOTA SUKABUMI
}

\section{IMPLEMENTATION OF FUNERAL AND CREMATION RETRIBUTION IN SUKABUMI CITY}

\author{
Puji Fauziah, Tuah Nur, Andi Mulyadi \\ Program Studi Administrasi Publik Fakultas Ilmu Administrasi dan Humaniora \\ Universitas Muhammadiyah Sukabumi \\ pfauziah14@gmail.com
}

\begin{abstract}
Abstrak
Penelitian ini bertujuan untuk mengetahui implementasi kebijakan retribusi pelayanan pemakaman dan pengabuan mayat di Kota Sukabumi yang diatur dalam Peraturan Daerah Kota Sukabumi Nomor 5 Tahun 2012. Peneliti menggunakan teori Edward III yang memiliki 4 dimensi. Dalam pelaksanaan kebijakan tersebut ditemukan berbagai permasalahan, yaitu kurangnya proses sosialisasi kepada masyarakat, sumber daya yang belum memadai, adanya petugas yang memberlakukan tarif tidak sesuai dengan peraturan daerah, dan belum optimalnya SOP. Penelitian ini menggunakan metode kualitatif. Untuk menentukan informan, peneliti menggunakan teknik purposive sampling dengan jumlah 10 informan. Pengumpulan data dalam penelitian ini melalui observasi, wawancara, dokumentasi. Dalam menguji keabsahan data penelitian menggunakan teknik triangulasi. Hasil penelitian mengungkapkan bahwa implementasi kebijakan retribusi pelayanan pemakaman dan pengabuan mayat belum maksimal karena masih kurangya sosialisasi secara langsung kepada masyarakat, kurangnya sumber daya manusia dan belum memadainya fasilitas, adanya pemberlakuan tarif yang tidak sesuai dengan peraturan daerah, SOP yang belum berjalan secara optimal.
\end{abstract}

Kata Kunci : Implementasi kebijakan, retribusi, pelayanan.

\begin{abstract}
The research was aimed at determining the implementation of retribution policy on funeral service and corpse cremation in Sukabumi City regulated in the Regional Regulations of Sukabumi City Number 5 Year 2012. The researcher applied the theory from Edward III having 4 dimensions. In the implementation of the policy, several problems were identified in terms of lack of socialization process to society, lack of manpower, staff applying fee not in line withthe applied local regulation, and un optimal SOP. The research utilized qualitative method. In order to find informants, purposive sampling technique was applied to
\end{abstract}


10 informans. The tecniques of collecting data deployed were observation, interview, and documentation. Triangulation techniques was utilized in order to test the validity of data. The results of the research convey that the implementation of retribution policy on funeral service and corpse cremation has not been maximum due to the lack of direct socialization to society, lack of manpower, un optimal facilities, inappropriate fee which is not in accordance with the regulations, and un optimal SOP.

\section{Keywords : policy implementation, retribution, service}

\section{A. Pendahuluan}

Berdasarkan dengan Undang-Undang Nomor 22 Tahun 2012 pada pasal 10 huruf $(\mathrm{k})$ salah satu penyediaan tanah utuk kepentingan umum yaitu untuk tempat pemakaman umum Pemerintah/Pemerintah Daerah. Pemakaman merupakan salah satu yang sangat dibutuhkan oleh masyarakat karena pada hakikatnya setiap manusia yang hidup di dunia ini akan membutuhkan pemakaman sebagai tempat terakhirnya, sehingga setiap daerah perlu adanya tempat pemakaman. Terkait dengan hal ini Pemerintah Kota Sukabumi juga memiliki kewajiban yang sama dalam penyediaan tempat untuk pemakaman.

Tempat pemakaman umum di Kota Sukabumi dikelola oleh UPT Pemakaman Dinas Lingkungan Hidup Kota Sukabumi yang berjumlah enam tempat pemakaman umum dengan berlandaskan pada Peraturan Daerah Kota Sukabumi Nomor 5 Tahun 2012 tentang Retribusi Pelayanan Pemakaman dan Pengabuan Mayat.
Retribusi menurut Undang-Undang Nomor 28 Tahun 2009 adalah pungutan daerah sebagai pembayaran atas jasa atau pemberian izin tertentu yang khusus disediakan dan/atau diberikan oleh Pemerintah Daerah untuk kepentingan pribadi atau badan. Retribusi yang dihasilkan dari retribusi pelayanan pemakaman dan pengabuan mayat merupakan salah satu sumber pendapatan asli daerah (PAD) yang dapat digunakan untuk berbagai keperluan umum pemerintah daerah. Dalam Peraturan Daerah Kota Sukabumi Nomor 5 Tahun 2012 pada pasal 1 retribusi pelayanan pemakaman dan pengabuan mayat adalah pungutan yang dilakukan oleh Pemerintah Kota Sukabumi kepada seluruh pemakai jasa penyelenggaraan pelayanan pemakaman dan pengabuan mayat. Untuk penagihannya menggunakan Surat Tagihan Retribusi Daerah (STRD) yang dalam waktu pertiga tahun dengan jumlah nominal yang telah ditentukan dan disesuaikan dengan jumlah luas tanah yang digunakan. 
Namun dalam pelaksanaan kebijakan tersebut masih ditemukan berbagai permasalahan, yaitu kurangnya proses penyaluran komunikasi berupa sosialisasi yang dilakukan mengenai Peraturan Daerah Kota Sukabumi Nomor 5 Tahun 2012 antara pihak pemerintah dan masyarakat sebagai ahli waris menyebabkan tidak meratanya pengetahuan mengenai adanya peraturan tentang retribusi pelayanan pemakaman dan pengabuan mayat. Hal tersebut selain berdampak kepada jumlah pendapatan retribusi sewa ulang tanah, kurangnya pegawai UPT Pemakaman yang bertugas sebagai penarik retribusi yang hanya berjumlah satu orang, belum memadainya fasilitas seperti penyediaan loket khusus bagi pembayaran retribusi sewa ulang tanah, adanya sikap petugas lapangan yang tidak sesuai dengan isi dari peraturan daerah dengan memberlakukan tarif penguburan yang berbeda, Standar Operating Prosedures (SOP) yang belum berjalan secara optimal. Berdasarkan pada berbagai permasalahan yang ada peneliti tertarik untuk melakukan peneleitian tentang implementasi kebijakan retribusi pelayanan pemakaman dan pengabuan mayat di Kota Sukabumi.

Beberapa tinjauan pustaka yang peneliti gunakan antara lain menyangkut kebijakan publik, implementasi kebijakan, pelayanan publik dan retribusi daerah. Kebijakan merupakan sebuah tindakan yang dilakukan dengan tujuan yang telah ditetapkan untuk mencapai kesejahteraan dengan memperhatikan dampak atau konsekuensinya, dalam prosesnya sebuah kebijakan dihasilkan dari usulan perorangan atau kelompok yang disesuiakan dengan kepentingannya. Dalam Tahir (2014 : 21-22) dikatakan bahwa terdapat lima hal yang berhubungan dengan kebijkan publik, yaitu :

1. Tujuan atau kegiatan yang berorientasi tujuan haruslah menjadi perhatian utama perilaku acak atau peristiwa yang tiba-tiba terjadi.

2. Kebijakan merupakan pola model tindakan pejabat pemerintah mengenai keputusan-keputusan diskresinya secara terpisah.

3. Kebijakan harus mencakup apa yang nyata pemerintah perbuat atau apa yang mereka katakan akan dikerjakan.

4. Bentuk kebijakan publik dalam bentuknya yang positif didasarkan pada ketentuan hukum dan kewenangan.

5. Tujuan kebijakan publik adalah dapat dicapainya kesejahteraan masyarakat melalui produk kebijakan yang dibuat oleh pemerintah.

Selanjutnya mengenai studi implementasi merupakan suatu 
kajian mengenai studi kebijakan yang mengarah pada proses pelaksanaan dari suatu kebijakan. Dalam praktiknya implementasi kebijakan merupakan suatu kegiatan yang begitu kompleks bahkan tidak jarang bermuatan politis dengan adanya intervensi berbagai kepentingan (Agustino, 2014 : 138). Model Impementasi Kebijakan Publik Edward III dalam Agustino (2014 : 149). Model implementasi kebijakan yang berspektif top down, menamakan model implementasi kebijakan publiknya dengan Direct and Indirect Impact on Implementation. Dalam pendekatan yang diterjemahkan oleh Edward III, terdapat empat variabel yang sangat menentukan keberhasilan implementasi suatu kebijakan, yaitu : 1) komunikasi; 2) sumberdaya; 3) disposisi; dan 4) struktur birokrasi.

$\begin{array}{lrr}\text { Variabel } & \text { pertama } & \text { yang } \\ \text { mempengaruhi } & & \text { keberhasilan } \\ \text { implementasi } & \text { suatu } & \text { kebijakan }\end{array}$
menurut Edward III adalah komunikasi. Implementasi yang efektif terjadi apabila para pembuat keputusan sudah mengetahui apa yang akan mereka kerjakan dan para implementator akan semakin dalam melaksanakan semakin konsisten dalam melaksanakan setiap kebijakan yang akan ditetapkan dalam masyarakat. Terdapat tiga indikator yang dapat dipakai (atau digunakan) dalam megukur keberhasilan variabel komunikasi, yaitu : transmisi, kejelasan, dan konsistensi;

Variabel kedua yang mempengaruhi keberhasilan implementasi kebijakan menurut Edward III yaitu sumberdaya. Dalam mengimplementasikan kebijkan indikator sumberdaya terdiri dari beberapa elemen, yaitu : staf, informasi, wewenang, fasilitas. Variabel ketiga menurut Edward III yaitu disposisi, hal-hal yag penting dalam disposisi yaitu : pengangkatan birokrat, insentif. Variabel keempat menurut Edward III yaitu struktur birokrasi. Dua karakteristik menurut Edward III yang dapat mendongkrak kinerja struktur birokrasi/organisasi kearah yang lebih baik, adalah : melakukan Standar Operating Prosedures (SPOs) dan melaksanakan fragmentasi adalah upaya penyebaran tanggungjawab kegiatan-kegiatan atau aktivitasaktivitas pegawai di antara beberapa unit kerja.

Mengenai retribusi daerah yaitu dikeluarkan atau dibayarkan kepada pemerintah daerah sebagai kompensasi atau balasa jasa atas pemakaian yang masyarakat gunakan dari pemerintah daerah. Menurut Prawirohardjono dalam Adisasmita (2014:109) retribusi daerah merupakan pungutan daerah sebagai pembayaran pemakaian atau karena memperoleh jasa pekerjaan, usaha atau atau milik daerah baik langsung 
maupun tidak langsung. Berdasarkan Undang-Undang Nomor 28 Tahun 2009 tentang Pajak Daerah dan Retribusi Daerah BAB VI yang menjadi objek retribusi adalah sebagai berikut:

1. Jasa umum;

2. Jasa usaha; dan

3. Perizinan tertentu.

Berdasarkan Undang-Undang Nomor 28 Tahun 2009 pada BAB IX tata cara pemungutan retribusi, yaitu retribusi dipungut dengan menggunakan SKRD atau dokumen lain yang dipersamakan. Dalam hal wajib retribusi tertentu tidak membayar tepat pada waktunya atau kurang membayar, dikenakan sanksi administratif berupa bunga 2\% (dua persen) setiap bulan dari retribusi yang terutang yang tidak atau kurang dibayar dan ditagih dengan menggunakan STRD. Penagihan retribusi terutang didahului dengan surat teguran. Tatacara pelaksanaan pemungutan retribusi ditetapkan dengan Peraturan Kepala Daerah.

Yang terakhir adalah mengenai pelayanan publik. Menurut Moenir dalam Mutiarin dan Arif Zaenudin (2014 : 91) pelayanan umum adalah kegiatan yang dilakukan oleh seseorang atau sekelompok orang dengan landasan faktor material melalui sistem, prosedur dan metode tertentu dalam rangka usaha memenuhi kepentingan oranglain sesuai haknya. Pelayanan dilakukan sebagai bentuk melayani seseorang untuk memeuhi kebutuhannya yang disesuaikan dengan hal yang dimilikinya berdasarkan peraturan yang berlaku.

Pelayanan pemakaman dan pengabuan mayat merupakan salah satu yang termasuk ke dalam jenis pelayanan jasa. Jasa pelayanan pemakaman dan pengabuan mayat adalah kegiatan Pemerintah Daerah berupa usaha dan pelayanan yang menyebabkan barang, fasilitas, atau kemanfaatan lainnya yang dapat dinikmati oleh orang pribadi atau Badan yang meliputi pelayanan pemakaman/penguburan termasuk pelayanan penggalian, pengurukan, pengadaan padung dan sewa tanah untuk penguburan/pemakaman seta pengabuan mayat.

\section{B. MetodePenelitian}

Penelitian ini menggunakan metode penelitian kualitatif yang menggunakan latar alamiah, dengan maksud menafsirkan fenomena yang terjadi (Denzin dan Lincoln dalam Satori dan Aan Komariah, 2011 : 23). Dalam penelitian ini peneliti memberikan batasan dalam kajian penelitian yang akan dilakukan dengan menggunakan teori menurut Edward III yang memiliki empat dimensi.

Untuk menentukan informan menggunakan teknik purposive sampling dengan jumlah 10 
informan. Dalam pengumpulan data dalam penelitian dengan metode observasi, wawancara, dokumentasi. Pengujian keabsahan data dilakukan dengan teknik triangulasi sumber, triangulasi waktu, dan triangulasi teknik. Sedangkan dalam menganalisis data dilakukan pengumpulan data, reduksi data, penyajian data hingga tahap kesimpulan.

\section{Hasil dan Pembahasan}

Penelitian ini dilakukan di UPT Pemakaman Dinas Lingkungan Hidup Kota Sukabumi mengenai implementasi kebijakan retribusi pelayanan pemakaman dan pengabuan mayat di Kota Sukabumi dengan menggunakan grand theory dari Erdward III yang terdiri dari empat dimensi, yaitu :

\section{Dimensi Komunikasi}

Dalam pelaksanaan kebijakan retribusi pelayanan pemakaman dan pengabuan mayat di Kota Sukabumi komunikasi yang dilakukan antara pihak pelaksana kebijakan antara UPT Pemakaman dan petugas lapangan sudah berjalan dengan baik, dengan dilakukannya pengawasan secara rutin oleh pihak UPT Pemakaman kepada petugas lapangan di tempat pemakaman yang bertujuan agar para pelaksana dapat mengetahui adanya peraturan daerah tentang retribusi pelayanan pemakaman dan pengabuan mayat serta dapat menerapkan peraturan tersebut dalam pelaksanaan tugasnya masing-masing. Namun komunikasi antara UPT Pemakaman dan masyarakat sebagai ahli waris belum berjalan dengan baik, sehingga komunikasi informasi yang tersampaikan belum jelas hal ini menyebabkan kurangnya pengetahuan ahli waris perihal jumlah besaran tarif retribusi sewa ulang tanah serta jangka waktu untuk melakukan sewa ulang tanah.

\section{Dimensi Sumber Daya}

Sumber daya dalam kebijakan retribusi pelayanan pemakaman dan pengabuan mayat di Kota Sukabumi masih belum memadai, baik dalam segi sumber daya manusia dimana pegawai di UPT Pemakaman masih kekurangan, terutama pada bagian staf retribusi yang hanya berjumlah satu orang dengan tugas untuk melakukan penagihan retribusi di seluruh tempat pemakaman yang dikelola oleh UPT Pemakaman Dinas Lingkungan Hidup Kota Sukabumi. Maupun fasilitas fisik berupa loket khusus untuk melakukan pembayaran retribusi sewa ulang tanah belum tersedia yang menjadikan pelaksanaan kebijakan retribusi pelayanan pemakaman dan pengabuan mayat di Kota Sukabumi kurang efektif.

\section{Dimensi Disposisi Atau Sikap Pelaksana}

Dalam mengimplementasikan kebijakan tentang retribusi pelayanan pemakaman dan pengabuan mayat di 
Kota Sukabumi sikap para pelaksana dalam memberikan pelayanan sudah dapat dikatakan baik, dengan adanya rasa ingin memberikan pelayanan terbaik bagi masyarakat serta para pekerja lapangan yang senantiasa selalu siap dan cekatan dalam menanggapi adanya permintaan untuk melakukan penguburan tanpa mengenal batas waktu. Meskipun demikian, masih adanya petugas lapangan yang memberlakukan besaran tarif untuk biaya penguburan yang tidak sesuai dengan yang telah tercantum dalam Peraturan Daerah Kota Sukabumi tentang retribusi pelayanan pemakaman dan pengabuan mayat yang disebabkan dengan kurang sesuainya besaran tarif yang telah ditentukan di dalam peraturan daerah dengan biaya perlengkapan untuk kebutuhan penguburan. Namun sikap acuh tak acuh pihak UPT Pemakaman yang disebabkan oleh tidak adanya keluhan dari masyarakat sebagai ahli waris menyebabkan tidak meratanya besaran tarif untuk biaya penguburan yang menyebabkan terjadinya perbedaan biaya penguburan disetiap tempat pemakaman umum.

\section{Dimensi Struktur Birokrasi}

Implementasi kebijakan retribusi pelayanan pemakaman dan pengabuan mayat di Kota Sukabumi sudah berlakunya Standard Operating Procedures (SOP), namun dalam pelaksanaanya masih dapat dikatakan belum optimal karena

belum meratanya SOP yang dilaksanakan, hal ini dapat dilihat dari masih ada sebagian ahli waris yang tidak mengumpulkan persyaratan yang dibutuhkan pada saat akan melakukan penguburan sehingga hal ini berdampak kepada kesulitannya untuk mendata ulang ahli waris untuk memberikan surat pemberitahuan terkait retribusi sewa ulang tanah.

Selain Standard Operating Procedures (SOP), penyebaran tugas dan tanggung jawab juga dapat menjadi faktor penunjang dalam meningkatkan kinerja para pegawai. UPT Pemakaman Dinas Lingkungan Hidup Kota Sukabumi sendiri memiliki tugas dan tanggung jawab yang jelas dan berbeda, hal ini dapat membantu dalam mengimplementasikan kebijakan dengan baik.

\section{Faktor}

\section{Implementasi \\ Retribusi}

\section{Pemakaman dan Pengabuan} Mayat di Kota Sukabumi

Faktor keberhasilan dari sebuah kebijakan, begitupun dalam impelementasi kebijakan retribusi pelayanan pemakaman dan pengabuan mayat di Kota Sukabumi mempunyai faktor pendukung untuk mencapai keberhasilan kebijakan tersebut, yaitu :

a. Adanya sumber atau dasar hukum yang menjadi 
landasan dalam pelaksanaan retribusi yaitu dalam Peraturan Daerah Kota Sukabumi Nomor 5 Tahun 2012 tentang Retribusi Pelayanan Pemakaman dan Pengabuan Mayat di Kota Sukabumi.

b. Adanya sikap yang baik dan cepat tanggap dalam menanggapi permintaan masyarakat sebagai ahli waris dalam melakukan penguburan serta dalam memberikan pelayanan penagihan retribusi sewa ulang tanah.

c. Pembagian tugas dan tanggung jawab yang jelas dan berbeda pada setiap pegawai.

6. Faktor

\section{Implementasi}

Retribusi

Pemakaman dan Pengabuan

Mayat di Kota Sukabumi

Selain dari faktor pendukung, dalam pelaksanaan kebijakan juga terkadang ditemukan faktor yang dapat menghambat tercapainya keberhasilan dari pelaksanaan kebijakan. Dalam impelementasi kebijakan retribusi pelayanan pemakaman dan pengabuan mayat di Kota Sukabumi yang menjadi faktor penghambat, yaitu :

1. Kurangnya sosialisasi langsung yang dilakukan oleh pihak UPT Pemakaman kepada masyarakat sebagai ahli waris sehingga kurang meratanya pengetahun ahli waris mengenai tarif dan waktu retribusi sewa ulang tanah.

2. Kurangnya sumber daya berupa fasilitas seperti tempat khusus atau loket khusus untuk melakukan pembayaran retribusi, serta kurangnya pegawai yang bertugas yang bertugas untuk melakukan penagihan retribusi.

3. Masih adanya petugas lapangan yang memberlakukan tarif retribusi penguburan yang tidak sesuai dengan Peraturan Daerah Kota Sukabumi Nomor 5 Tahun 2012.

4. Belum optimalnya pelaksanaan Standard Operating Procedures (SOP) sehingga akan menyulitkan UPT Pemakaman pada saat akan memberikan surat pemberitahuan mengenai retribusi sewa ulang tanah.

\section{Penutup}

Berdasarkan hasil penelitian yang dilakukakn oleh peneliti dengan mengumpulkan data-data di lapangan, dilihat dari teori Edward III peneliti mengambil kesimpulan sebagai berikut :
1. Dalam
pelaksanaan
implementasi
kebijakan
retribusi
pelayanan
pemakaman dan pengabuan 
mayat di Kota Sukabumi, komunikasi yang

dilaksanakan antara pihak

pemerintah yaitu UPT

Pemakaman, petugas

lapangan sudah terlaksana dengan baik agar setiap pegawai mengetahui mengenai adanya peraturan daerah. Namun komunikasi antara UPT Pemakaman dan masyarakat sebagai ahli waris dalam Peraturan Daerah Nomor 5 Tahun 2012 belum optimal, karena masih adanya masyarakat sebagai ahli waris yang tidak mengetahui tentang adanya retribusi pelayanan pemakaman dan pengabuan mayat sehingga masih terdapat ahli waris yang belum membayar retribusi pelayanan pemakaman dan pengabuan mayat dalam bidang sewa ulang tanah.

2. Sumber daya pada implementasi kebijakan retribusi pelayanan pemakaman dan pengabuan mayat di Kota Sukabumi masih belum memadai, baik dari sumber daya manusia yang masih kekurangan pegawai serta dari fasilitas yang belum tersedianya tempat atau loket khusus untuk melakukan pembayaran retribusi.
3. Disposisi yaitu sikap dan kecenderungan dari para pelaksana belum optimal. Meskipun pegawai sudah memberikan pelayanan yang baik dan sigap pada saat pelayanan pemakaman namun masih ada petugas lapangan yang memberlakukan besaran tarif penguburan yang tidak sesuai dengan tarif yang telah tercantum dalam Peraturan Daerah Nomor 5 Tahun 2012 tentang Pelayanan Pemakaman dan Pengabuan Mayat.

4. Struktur birokrasi pada pelaksanaan kebijakan retribusi pelayanan pemakaman dan pengabuan mayat di Kota Sukabumi belum optimal dikarenakan Standard Operating Procedures (SOP) yang ada tentang pelayanan penguburan belum dilaksanakan oleh semua masyarakat sebagai ahli waris yang akan mengajukan izin penguburan.

Berdasarkan dengan kesimpulan yang telah dikemukakan, maka peneliti memberikan saran sebagai berikut :

1. Komunikasi perlu diadakannya sosialisasi secara langsung yang dilakukan oleh UPT 


Pemakaman mengenai
peraturan daerah tentang
retribusi
pemakaman dan pelayanan
mayat agar masyarakat
mempunyai pengetahuan
sehingga dapat membayar
kewajibannya sesuai dengan
peraturan yang berlaku.

2. Sumber daya manusia yang ada di UPT Pemakaman terlihat dari pelaksanaan penagihan retribusi sewa ulang tanah harus diimbangi dengan jumlah yang mencukupi, agar hasil yang didapatkan bisa lebih maksimal dan perlu adanya penyediaan fasilitas tempat berupa loket khusus untuk melakukan pembayaran retribusi agar dapat memudahkan proses pembayaran bagi ahli waris serta dapat mendukung pelaksanaan kebijakan retribusi pelayanan pemakaman dan pengabuan mayat.

3. Perlunya meningkatkan pemahaman tentang isi dari Peraturan Daerah Nomor 5 Tahun 2012 tentang Pelayanan Pemakaman dan Pengabuan Mayat terutama pada pasal yang membahas mengenai besaran tarif penguburan kepada petugas lapangan sehingga tidak adanya perbedaan dalam memberlakukan tarif penguburan.

4. Sttruktur birokrasi mengenai Standard Operating Procedures (SOP) pada pelayanan penguburan harus diperketat sehingga seluruh ahli waris dapat mengumpulkan segala bentuk persyaratan dokumen yang nantinya dapat memberikan kemudahan bagi UPT Pemakaman dalam pengelolaan data masyarakat sebagai ahli waris.

\section{Daftar Pustaka}

Adisasmita, Raharjo. 2014. Pengelolaan Pendapatan \& Anggaran Daerah. Yogyakarta: Graha Ilmu.

Agustino, Leo. 2014. Dasar-dasar Kebijakan Publik Berbasis Dynamic Policy Analisys. Bandung: Alfabeta.

Mutiarin, Dyah \& Arif Zaenudin. 2014. Manajemen Birokrasi dan Kebijakan. Yogyakarta: Pustaka Pelajar.

Peraturan Daerah Kota Sukabumi Nomor 5 Tahun 2012 tentang Pelayanan Pemakaman dan Pengabuan Mayat.

Satori, Djam'an \& Aan Komariah. 2011. Metodologi Penelitian Kualitatif. Bandung: Alfabeta.

Tahir, Arifin. 2015. Kebijakan Publik dan Transparansi Penyelenggaraan 
Pemerintahan

Daerah.

Bandung: Alfabeta.

Undang-Undang Nomor 28 Tahun

2009 tentang Pajak Daerah dan

Retribusi Daerah 